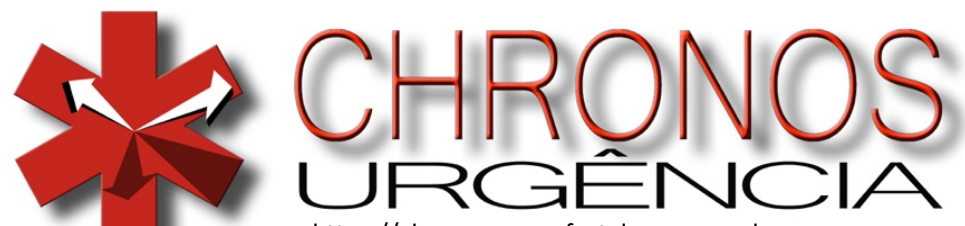

https://chronos.samu.fortaleza.ce.gov.br elSSN 2763-5872

\title{
Editorial
}

\section{Vidas e Tempos}

\author{
Lives and Times \\ Vidas y Tiempos
}

Cláudio Roberto Freire de Azevedo ic

<claudio.azevedo@samu.fortaleza.ce.gov.br>

NEP SAMU 192 - Regional Fortaleza

Rua Padre Guerra, 1350, Parquelândia, CEP 60455-365, Fortaleza, CE, Brasil.

Palavras-chave: Vida, Tempo, Temporalidade, Campo Quântico

Hoje nossa revista manifesta-se viva... biólogos contemporâneos definem entidade viva como aquela entidade capaz de se criar e se regenerar de modo constante, de produzir a rede necessária para a sua própria transformação, reforçandose enquanto individualidade em relação com o meio em que vive: um sistema autopoiético para Humberto Maturana; uma forma de organização sistêmica em que os sistemas, como um todo, produzem e subsistem seus próprios componentes.

Pretendemos ser referência nacional e internacional na linha de urgência e emergência e já saímos na frente, ousando sermos os primeiros nessa linha de publicações no país. Em 2022 far-se-á 20 anos da normatização federal "mãe" da urgência (Portaria GM/MS № 2048, de 05 de novembro de 2002) e queremos presentear o país com um canal e um incentivo adicional às publicações em urgência e emergência. 
É um pensamento audacioso e, realmente, somos gratos a todos que assumiram conosco esse desafio de sermos pioneiros e construirmos, no tempo, mais um capítulo dessa história. Agora nos debruçamos ante Chronos para perceber aquilo que emerge e aquilo que urge. Como é o nosso agir quando experienciamos "o que emerge daquilo que urge" ou "o que urge daquilo que emerge"?

Agimos conforme o que se reflete em nós. Tendemos a refletir o mundo e as coisas como algo que muda com o tempo, com suas urgências e emergências, mas é preciso ver o tempo de outra forma, afinal o mundo e as coisas que conhecemos (energia e partículas, tempo e espaço) não têm existência por si e podem ser "somente" a manifestação relacional de campos sobre campos, um campo quântico covariante que cria a realidade que refletimos.

Na realidade nada muda com o tempo, as coisas mudam umas em relação às outras, num movimento constante e impermanente. Precisamos mudar o nosso ponto de reflexão: discernir, do eterno jorrar do tempo sem tempo (Aión), o tempo dos homens (Chronos), o tempo de Deus (Kairós) e a plenitude do agora (Pleroma). A vida é o processo, a sequência de interações que fazem surgir relações complexas entre "inanimados" e os transformam em sistemas "animados".

Esse primeiro número tem como tema "Vidas e Tempos". Movimento é vida e vida é o nosso foco. Em fluxo contínuo, vamos experienciar o que emerge, afinal: do conhecimento infinito à ignorância infinita, só sei que nada sei...

\section{Direitos autorais}

Este artigo está licenciado sob a Licença Internacional Creative Commons 4.0, tipo BY-NC (https://creativecommons.org/licenses/by-nc/4.0/deed.pt BR).

\section{(ब) $(1) \Theta$}

Keywords: Life, Time, Temporality, Quantum Field

Palabras clave: Vida, Tiempo, Temporalidad, Campo Cuántico 